\title{
The four modes of thinking framed by utopian discursivity; Or why we need Utopia
}

\author{
Fátima VIEIRA
}

CETAPS - Centre for English, Translation and Anglo-Portuguese Studies, University of Porto, Portugal

vieira.mfatima@gmail.com

\section{Abstract}

This article stands for the idea that Thomas More was a "founder of discursivity". Based on this notion (which Michel Foucault applied to Karl Marx and Sigmund Freud), the article examines the four modes of thinking - prospective thinking, critical thinking, holistic thinking and creative thinking - that are framed by "utopian discursivity". Ultimately, the description of these modes of thinking aim to ground the author's conviction that, because of the way they organise our reflection on the possibilities for the development of our society, they are the tools we need to construct a better future.

Keywords: Thomas More; utopian thinking; discursivity; future

\section{Utopian discursivity}

In his book on curiosity (2015), Alberto Manguel explains what happens when we read a piece of "great literature", the sort of book that is characterised by a "multi-layered complexity": in spite of all our efforts, we never manage to capture its essence, and this is why we are to return to the book, over and over again, hoping, if not to reach its depths, at least to go a step further in its understanding. This, Manguel suggests, is a never-ending task: "generations of readers cannot exhaust these books", but have instead contributed to the construction of a "palimpsest of readings that continuously re-establishes the book's authority, always under a different guise" (7). In the end, the book is richer as a result of what Manguel calls "the art of reading":

Reading is a craft that enriches the text conceived by the author, deepening it and rendering it more complex, concentrating it to reflect the reader's personal experience and expanding it to reach the farthest confines of the reader's universe and beyond. (9)

Further in his book, Manguel describes how he has learned to find in books "clues to [his own] identity" (49), how the words of others, being "valid instruments for inquiry", have helped him think (83).

Although Manguel does not mention Utopia in his book, Thomas More's masterpiece ftlustrates rather well the case of a complex and multi-layered book. The history of utopian literature is in fact based on different interpretations of it by generations of readers who have tried to update the book's message to their own age, reflecting on different ways of constructing the future. But I believe that Utopia goes beyond the idea of a mere "palimpsest of readings": I find in Thomas More the qualities that Michel Foucault acknowledged in Karl Marx and Sigmund Freud when he depicted them, in "What is an author?", as "founders of discursivity"," claiming that they have produced the "possibilities and the rules for the formation of other texts" (FOUCAULT 1984: 114). ${ }^{2}$ I am not thinking here of the fact that Thomas More invented a new literary genre, with a set of narrative conventions; I am thinking, instead, of the way More offered a totally different perspective on the world, no doubt framed by the age he lived in (and for the advancement of which he contributed), namely by the way Humanism valued the agency of human beings. This new perspective, which in rigour corresponded to a revolution in thought, had as its foundation act a practice of thinking where the discourse on the Other is centred on oneself. In true fact, as Andrew Hadfield has noted, the inhabitants of the island of Utopia are "dislocated Europeans", dealing with the same problems that afflicted the Europeans of the $16^{\text {th }}$ century (HADFIELD 
2007: 7).

Describing the characteristics of the texts by the "founders of discursivity", Foucault further clarifies that these are texts we are always to go back to; he suggests, however, that

[t]he return is not a historical supplement which would be added to the discursivity, or merely an ornament; on the contrary, it constitutes an effective and necessary task of transforming the discursive practice itself." (FOUCAULT 1984: 116)

This, according to Foucault, would be the main difference between the revolution in thought orchestrated by Freud or Marx, and the revolution motivated by scientific discoveries:

a re-examination of Freud and Marx will inevitably" result in changes in Freudianism or Marxism, whereas to reexamine Galileo's texts would not bring a change in mechanics. (116)

This acknowledgement that "the initiation of a discursive practice is heterogeneous to its subsequent transformations" (115) is instrumental to the understanding of utopian discursivity. In fact, I believe that the expansion of utopian discursivity is crucial for the understanding not only of contemporary utopian thinking, but also of Thomas More's founding text as well.

\section{Foucault suggests that:}

to limit psychoanalysis as a type of discursivity is (...) to try to isolate in the founding act an eventually restricted number of propositions or statements to which, alone, one grants a founding value, and in relation to which certain concepts or theories accepted by Freud might be considered as derived, secondary, and accessory." (116)

This is what I am trying to examine in this article. As I said above, I believe the founding act of utopian discursivity to be found in the way the discourse on the Other is transformed into a discourse on oneself. I further believe that it is possible to identify in utopian discursivity a number of propositions or, to be more precise, modes of thinking, approaches to the world and to the role that we are to play on it, which I will label as prospective thinking, critical thinking, holistic thinking, and creative thinking. My main aim here is to build an argument in defence of utopian thought. I will argue that we need utopia because, through the four modes of thinking it entails, it provides us with the tools we need to change society.

\section{The four modes of utopian thinking}

\subsection{Prospective thinking}

We need utopia, first of all, because it helps us to set goals. The best definition of utopia, in this sense, I have ever come across has been offered by the Argentinian film director Fernando Bírri, who famously said that utopia is something that we set on your horizon: we know that we will never reach it, that every time we take ten steps forward, it will walk ten steps away; but we need it to proceed, as it forces us to walk. ${ }^{3}$

Utopian thinking inspires us to be ambitious while asking the inaugural utopian question "what do we want for our society?" Furthermore, it impels us to inflate the possibilities of our future with what Ernst Bloch called a "surplus of desire". For Bloch, it is the subsistence of desire (something he recognises to exist in man as an ontological category), even after our dreams have been fulfilled, that ensures the permanence and dynamics of utopia (BLOCH 1976: 216-217). The notion of incompleteness is thus a vital propeller for the development of societies.

It is important to note that this prospective attitude, even though it is inflated by a surplus of desire, is not disconnected from reality. It is quite the opposite: in all truth utopian thinking always moves from the real, which it rejects; as Paul Ricoeur put it, the utopian element implies a capacity for denial and refusal of the prevailing ideology (RICOEUR 1986: 313). But just as the utopian encounters with the other entail a search for a better solution for our society, the imagination of different futures for humanity implies a search for recipes to be applied in the here and now, as Pierre Furter has contended. Furter has further argued that this search is carried on with the awareness that 
utopia will never offer final truths: the truths it offers are provisional, as they result from the dialectic transforming movement they establish with the real world (apud.GREIS 1996: 32). The truths put forward in the framework of utopian thinking are thus transitory; to resort to Fernando Bírri's metaphor of the ten steps towards the horizon, utopian discursivity provides us with time to, after every ten steps, critically observe reality and reset the horizon for the inaugural question "what do we want for our society?"

There are two more things that are specific to prospective thinking. The first has to do with the idea of future it deals with; the second, with its intentionality. In utopian thinking, the future is not to be seen as something that is bound to happen, but as a network of possibilities, a distinction which is conveniently conveyed in French by the existence of two parallel concepts, those of futur and avenir $^{4}$. As Gérard Klein explains, the concept of futur translates the perspective which dominated from Antiquity to the 17th century, the idea that the future is the continuity of the past and of the present, and that it is certain that it will happen; for that reason people tried to predict it, in a prophetic attitude. But the birth of euchronia, in the late 18th century, signalled a new way of thinking about the future, adequately represented by the concept of avenir. As Klein clarifies, the avenir is more complex and larger than the futur, as it includes everything that may happen, everything we may invent (255-7). It is this notion of avenir, of a multiple, plural, unpredictable future offering a myriad of very interesting possibilities that utopian prospective thinking takes on.

But the idea of prospective thinking also implies a particular intentionality when we are thinking about the future. The etymological Latin roots of prospective indicate that it is the result of the juxtaposition of the prefix pro (forward) and of the suffix tivus (intensity of action) to the verb specere (pro+specere+tivus). Thus, what is important about prospective thinking is the intensity of the action of looking into the future which results in an intentionality: the future is researched and explored so that we may anticipate what will happen. It is important to note here that when the word prospective was imported into English it lost part of its original meaning, which has been retained, however, by Romance languages: while in English prospective means "likely to be or become something specified in the future" or "likely to happen"5, in Romance languages such as Portuguese, Spanish, French and Italian the word conveys the notion of exploring ahead, an idea which is still to be found in the English noun prospection (as in gold or oil prospection).

There is another reason lam calling this kind of thinking prospective. I believe it resonates the principles of the system of thinking which Gaston Berger described in the mid-20th century (BERGER 1964; BERGER 1967). As Michel Godet has clarified, la prospective, as it is called in French, is a state of mind which entails imagination and anticipation that inspires hope and leads to will (1999: 8); it is a methodological tool and a system of analysis that integrates a set of techniques that promotes imagination and is based on the idea that anticipation encourages action (1999: 5). The prospective, as Godet calls it in English ${ }^{6}$, goes beyond the imagination of future scenarios. It starts by looking at the future as the object of desire, as the utopia which provides the present with a direction and a meaning (2006: 334) ${ }^{7}$. The prospective differs from extrapolative thought, which is a common method in social sciences. Instead of trying to devise which tendencies may shape the future, the prospective gives priority to desire and only afterwards reflects on the strategy, i.e., on the path to reach the goals that have been set; in the late 1980s, this came to be known as strategic prospective (GODET 1999: 4). It is thus a methodology that moves from the future to the present, as the reflection on the present is promoted in light of what the future may become.

Utopian discursivity is also deeply focused on images of a desirable future. 
However, its logic differs from that of strategic prospective in that it relies on a hypothesis approach. Although it is guided by the inaugural question "what do we want for our society?" that provides us with a horizon towards which we are to walk, next utopian prospective thinking tests the exploratory question "what if?", in order to assess the different possibilities of the paths available. There is, besides, the very basic difference derived from the fact that strategic prospective is, above all, a tool for the strategic management of companies and other institutions. Nevertheless, I believe that Gaston Berger's famous assertion that “looking at the future disturbs not only the future but also the present" (Apud. GODET 2006: 5) may well be applied to prospective utopian thinking as well.

\subsection{Critical thinking}

The second reason why we need utopia has to do with the critical thinking logic incorporated into the utopian discursivity. In fact, how could we ever responsibly decide which path to take without being sure of the accuracy, credibility, impartiality, relevance, and substantiality of the data that we will have to use in order to validate our choice? As it happens with critical thinking, our conclusions (that will validate the choice of the path to take) must be consistent and reliable, and be the logical, sequential, and progressive outcome of a careful consideration of data that can be easily verified and validated. Thus, the choice of the utopian road will imply the mastery of the six core skills of critical thinking: interpretation, analysis, evaluation, inference, explanation, and selfregulation. Utopian thinkers must have the characteristics of critical thinkers, as well as a strong sense of consequence that will provide them with the capacity to readily reconsider and revise their views when necessary. This is a quality that utopian thinkers should never lack, as it is the instrument that will allow for the continuous verification and redefinition of the horizons they are aiming at.
There are three more things that utopian thinkers have in common with critical thinkers. First, the capability to decentre the issue they are dealing with from their own interests and to include, in the redefinition of their interests, the interests of other people (that is why the inaugural question is inclusive in its formulation: "what do we want for our society?"); second, their ability to resist the influence of preconceived ideas and prejudices; and third, their capacity for thinking differently, for trying to devise new ideas, new solutions, and for being creative.

\subsection{Holistic thinking}

The third reason why we need utopia is because it provides us with holistic thinking, the only mode of thinking that, according to Edgar Morin, will eventually lead us to understanding. In his book $L a$ Voie pour l'avenir de l'humanité [The Path to the future of Humanity] (2011) Morin stands for the idea that the crisis we are living in - which is also a crisis of imagination - has a cognitive nature. As knowledge has been cut into many small bits, being taught in non-communicating subjects that are offered to students at university, we are led to misunderstand the information we are given: because we lack a larger view, we will never be able to contextualise, organise and understand it (2011: 239). As Morin says, if we observe separately each thread that composes a tapestry, we will never be able to perceive and enjoy the beauty of its pattern (253).

Morin contended in his Introduction à la Pensée Complexe [Introduction to the Complex Thought] (1990) that ideas and thoughts are complex; the modern tendency to clarify them by reducing them to small units and describing them partially prevents us from understanding their complexity, the way they relate to each other (thus establishing a relationship of complementarity) and the way they contradict each other (thus establishing a relationship of antagonism). It is only when we come to understand ideas in their complexity, when we accept that they are multidimensional and that they can be at 
the same time complementary and contradictory, that we will have access to knowledge (MORIN 1990: 10) - and, I would add, that we will be able to practise utopian thinking.

Utopian holistic thinking is capable of giving an adequate answer to the problems we are facing today because the crisis we live in is systemic: it has an economic, social, political, and ecological nature, and each part is interconnected with the other. It has, furthermore, a global expression: although some of the problems have clear local origins, they have given rise to other problems on a universal scale. As Ruth Levitas has explained, utopian models rely on a holistic view, as they reveal an acute awareness of the fact that societies work as systems (2007: 69). By incorporating the principles of multidimensional analysis, utopian thinking provides utopian thinkers with the qualities they need to address systemic problems. Moreover, this awareness of the systemic nature of the problems leads to decisions entailed by attentiveness to the possible consequences of actions and paths we may have opted to take. In a world that has local problems that have globat roots or repercussions (and vice-versa), only a holistic approach will provide us with reasonable, practical answers.

\subsection{Creative thinking}

Finally, we need utopian thinking because, by inviting us to think about alternatives, it fosters creativity. Utopian accounts always involve estrangement as they confront us with a diversity of new possibilities, with the description of multiple worlds that test a myriad of "what if?" hypotheses. This exposure to difference is of paramount importance: with utopian thinking, we escape the mere replication of existing knowledge and walk towards the creation of new knowledge.

This creation of new knowledge happens when someone dares to look out of the corner of his or her eye, as the Portuguese writer Gonçalo M. Tavares explains:
What is observed from the centre of one's eye is the obvious, what is shared by the multitude.

In Science, as in the world of inventions, observing out of the corner of one's eye is seeing the detail, that thing which is different and which may be the start of something meaningful.

Observing the reality out of the corner of one's eye, i.e.: thinking slightly to the side. From here all the important scientific theories were born. (2006: 75)

Thinking out of the corner of one's eye is then having the capacity to see things that other people are not able to see; it is having a wider angle of vision. When talking about utopia, Eduardo Galeano insists on this idea: "There are many realities wishing to be born" - he says. "They are just waiting for us to imagine them so that they can be born." 8 The problem is that we are not trained to see things that are not familiar to our eyes. The famous example of the Portuguese vessels and the Indians indicate that this is not a new problem. I am referring to the fact that, according to historical accounts, when the Portuguese vessels arrived in Brazil, the natives did not understand what they were. They had never seen a large ship before, so they perceived them as gods watching them from the horizon, as they believed that gods lived in the water. The lack of a familiar reference prevented them from seeing what they really were - large ships. In Tools for Conviviality, Ivan Illich explained what the problem is:

Our brain has been so deformed by the society we live in and by our habits of thought that we do not even dare to think about other possible forms of organisation. The question is that we are used to accepting that there is just one way of using things, but there is always not one way but at least two ways of using, for instance, a scientific discovery, two ways that are fundamentally contradictory. (1975: 12)

According to Illich, we have been trained to accept instead of to imagine; we have almost completely lost the power to dream of a world where all people would have the right to speak and to be heard, where there are no limits to creativity, where everyone and every single person may change his or her life (34). 
And still, the sort of creativity required by utopian thinking does not imply the creation of anything radically new. Boaventura de Sousa Santos explains that what utopian thinking requires us to do is to combine what already exists in new ways and new scales. As the Portuguese sociologist says, it is a matter of taking to the centre what used to be on the margins, and to devise the consequences of that change (1995: 479).

\section{Conclusion}

Utopian discursivity has no doubt changed since the publication of More's Utopia. To start with, the prospective attitude related to the concept of future as an avenir is not to be found in the founding text, as the society Raphael Hythloday describes is not set on the future but on a distant island. The exploration of the "what if?" hypotheses is at the basis of More's text, though. The prospective attitude also permeates Utopia in the sense that, as has so often been remarked, the description of the utopian island is not to be seen as More's ideal, as the final truth, but as the illustration of an alternative and an incentive for the reader to search for other alternatives. Right from the beginning, the utopian discourse was thus set as a movement of denial of the prevailing ideology; the idea of incompleteness that ensures the dynamics of utopia is made clear when Thomas More, the narrator, dismisses Raphael Hythloday "praising both [the Utopian's] institutions and his communication" and takes him by the hand saying that they would choose another time to weigh and examine the same matters" (1988: 135).

Critical thinking is also present in More's Utopia and is rendered evident by the analysis of the European society of the early 16th century, which Hythloday rejects and against which the island of Utopia is described. Holistic thinking too prevails in More's text, where the fact that societies work as systems is evinced by the careful description of the consequences of the abolition of private property at the level of political, economic, and social life.
Creative thinking is at the very basis of the Morean text. In fact, the "what if?" hypothesis that inspires utopian discursivity is founded upon a combination of what already existed, but on a new scale. The founding text of the utopian tradition, though, was restricted by a negative perspective on the capability of human beings to overcome the limitations cast on them because of the original sin. Creative thinking was thus conditioned by the coeval conviction that, as the human being was sinful, the only way of ensuring social peace would be by creating a set of laws destined to restrain his or her actions. A more optimistic view, which would be typical of the Enlightenment, would eventually lead to the imagination of societies based on an unlimited exploration of human capabilities. Nowadays, since Modernity has put the human being right at the centre of the universe, utopias are based on the presupposition that change will be brought about by human action.

Utopian discursivity has changed over the centuries; the four modes of thinking I have described certainly testify to those changes. But it is because of these changes, this adaptation to new times and new challenges, that utopian discursivity is so meaningful to our days and this is also why More's text proves to be so exhaustingly re-readable.

\section{Bibliography}

BERGER, G. Étapes de la prospective. Paris: Presses Universitaires de France, 1967.

-... Phénoménologie du temps et prospective. Paris: Presses Universitaires de France, 1964.

BLOCH, Ernst. Le Principe Espérance. Transl. Françoise Wuilmart. Paris: Gallimard, 1976.

FOUCAULT, Michel. Foucault Reader. Ed. Rabinow, Paul London: Penguin Books, 1984.

GODET, Michel. Creating Futures: Scenario Planning as a Strategic Management Tool. Preface by Joseph F. Coates. Transl. Adam Gerber and Kathryn Radford. London: Economica, 2006.

-.-. Manuel de prospective stratégique. Paris: Dunod, 1999.

GREIS, Yvonne dos Soares dos Santos. "O Elemento Utópico no Pensamento de Pierre Furter." MA thesis. Universidade Estadual de Campinas, 1996.

HADFIELD, Andrew. Literature, travel, and colonial writing in the English Renaissance, 1545-1625. Oxford: Clarendon Press, 2007. xiv, 305 p. ISBN: 978-0-19-923365-6.

ILLICH, Ivan. Tools for Conviviality. Glasgow: Fontana \& Collins, 1975. 
LEVITAS, Ruth. "The Imaginary Reconstruction of Society: Utopia as Method." In Utopia Method Vision: The Use Value of Social Dreaming. Eds. MOYLAN, Tom and Raffaella BACCOLINI. Ralahine utopian studies v. 1. Berne: Peter Lang, 2007. 4768. ISBN: 978-3-03910-912-8.

MANGUEL, Alberto. Curiosity. New Haven: Yale, 2015.

MORE, Thomas. Utopia. Transl. Ralph Robinson. London: Everyman's Library, 1988.

MORIN, Edgar. La voie: pour l'avenir de l'humanité. Paris: Fayard, 2011. ISBN: 9782213655604.

-.-. Introduction à la pensée complexe. Paris: Esf,

${ }^{1}$ In many theoretical texts written in English, the word Foucault has coined (discursivity) is spelt differently (discoursivity). In this article, I am using the word as it was proposed by Foucault to evince that I am subscribing to his definition of the concept.

${ }^{2}$ According to Foucault, this discursivity only emerges in the $19^{\text {th }}$ century, Marx and Freud being the most obvious examples. However, I believe that More falls into this category as well, as he offered a way of critically reflecting about the world that has been transformed by subsequent authors.

${ }^{3}$ It was Eduardo Galeano who attributed this definition of utopia to Fernando Bírri in a YouTube video clip that became viral on the Internet (available https://www.youtube.com/watch?v=mpgH(B8QdQ).

${ }^{4}$ This is in fact the case with all the Romance languages.

5 http: //www. merriamwebster.com/dictionary/prospective

6 La prospective is often translated into English as future studies or just foresight, but the translation limits the scope of the concept
1990. 158 p. ISBN: 2-7101-0800-3.

RICOEUR, Paul. Lectures on Ideology and Utopia. Ed. TAYLOR, George H. New York: Columbia University Pres, 1986.

SANTOS, Boaventura de Sousa. Toward a New Common Sense: Law, Science and Politics in the Paradigmatic Tradition. New York: Routledge, 1995.

TAVARES, Gonçalo M. Breves Notas sobre Ciência. Lisboa: Relógio D’Água, 2006.

to little more than the imagination of future scenarios, often within the logic of scenario entertainment. I do subscribe to Godet's option of anglicizing the French word in order to keep its original meaning (GODET 2006: 329, 333).

${ }^{7}$ Godet explains how the prospective, as a system of thinking, regains the idea of utopia as a powerful tool for the construction of the future: "By considering desire as a productive force for the future, we rehabilitate the concept of subjective utopia, thus reuniting imagination and scientific logic. Like many terms, utopia is too often used as synonymous with impossible. Etymologically ou-topos, coming from Greek, means a non-place; i.e., a place that does not exist. However, this does not exclude an eventual future existence. Utopia, as a virtual object of desire, is the source from which action takes its meaning and direction (Godet, 2006: 8).

${ }^{8} \mathrm{Cf}$. TV show O Tempo e o Modo, broadcast by Portuguese National Television. Available at https: / / www.youtube.com/watch?v=LmwiYpkbKM. 